\title{
CHARACTERIZATION OF MATERIALS BY VIBRATION TECHNIQUE
}

\author{
M. H. Mohd Akil Tan, N. L. Tajul Lile, F. Mat and S. YaACob \\ School of Mechatronic Engineering, Universiti Malaysia Perlis (UniMAP), \\ Ulu Pauh, 02600 Perlis, Malaysia. \\ hilmanakil@yahoo.com
}

\begin{abstract}
This paper presents an experimental investigation of two different kinds of plates of materials namely glass and stainless steel by experimental modal analysis. The materials are excited by an impact hammer to perform resonant vibration where the characteristics of the resonance are acquired. One most important characteristic is the natural frequency where it is known that different material having undergone resonant vibration exhibit different specific natural frequencies to it. The natural frequencies and corresponding mode shapes are used as the parameters of determining the structural properties of these materials. The vibration analysis is done using the LMS instruments and software where Frequency Response Function (FRF) measurement technique is employed in determining the natural frequencies. The structural properties are established based on the obtained natural frequencies and geometries of the materials using the expression from available literature. The elastic moduli obtained for glass and stainless steel are 66.08 Gpa and 193.26 GPa.
\end{abstract}

\begin{abstract}
ABSTRAK: Kertas ini membentangkan kajian mengenai dua bahan plat yang berbeza iaitu kaca dan keluli tahan karat dengan menggunakan analisis ragaman eksperimental. Getaran resonans dijalankan dengan menguja bahan-bahan tersebut dengan tukul hentaman dimana ciri-ciri tertentu diperolehi. Frekuensi asli merupakan satu daripada ciri utama, dimana ianya diketahui bahawa bahan yang berbeza akan mengalami getaran resonans yang menghasilkan frekuensi asli tertentu. Frekuensi asli dan bentuk ragam yang berpadanan digunakan sebagai parameter dalam menentukan sifat-sifat struktur bahan ini. Analisis getaran dijalankan dengan menggunakan peralatan LMS dan teknik ukuran perisian Fungsi Frekuensi Sambutan (Frequency Response Function $(F R F)$ ) untuk menentukan frekuensi asli. Sifat-sifat struktur ditentukan berdasarkan frekuensi asli dan bahan geometri, yang diperolehi daripada pengungkapan bahan sumber bacaan yang sedia ada. Modulus keanjalan yang diperolehi untuk kaca adalah 66.08 GPa dan untuk keluli tahan karat adalah 193.26 Gpa.
\end{abstract}

KEYWORDS: modal analysis; resonant vibration; natural frequency; nondestructive testing; FRF measurement; glass; stainless steel; Young's modulus.

\section{INTRODUCTION}

The study of materials characterization is important in knowing more about the behavior of the materials so that the utilization of the materials could be varied and used to the utmost potential. Knowledge of materials characterization is widely applied in the area of failure analysis to prevent engineering breakdown especially the very much undesirable catastrophic and cascading ones. In the area where safety, reliability and quality control are highly 
considered, the continuous development of analysis technique and measurement technology for materials characterization becomes inevitable.

One prominent aspect of materials characterization is the determination of elastic properties for materials by investigating the corresponding elastic constants namely Young's Modulus $(E)$, and Poisson's ratio (v). As meticulously reviewed in [1], various techniques have been developed for characterizing materials by their elastic properties. These variation of techniques could be classified into two major methods: static and dynamic.

Static methods are based on determination of specimen's stress and strain during standard mechanical testing. The specimens need to conform to certain specific shape and size for testing. One example of such test is the tensile test using Universal Testing Machine (UTM) where the specimens are shaped like a dog bone to specific length and thickness. Graph of stress and strain is plotted from the test and used to determine the mechanical behaviour of the specimens. The desired $E$ is attained from the slope of the linear region of the stress-strain graph. The test often requires a certain range of deformation of the specifically sized and shaped specimen for measurement of $E$. It is a destructive test as the specimens are usually tested until failure or reaches plastic region hence can no longer be used for further investigation.

Meanwhile, dynamic methods are nondestructive methods allowing variation in specimens' shapes and dimensions. Materials could be repeatedly tested through range of temperatures and conditions. There are two types of dynamic methods namely ultrasonic method and resonant method. Ultrasonic method involves the quantification of transit time of wave propagation through materials while resonant method involves the measurement of natural frequencies and the associated modal shapes to acquire the desired elastic constants.

Resonant method or modal vibration testing has been widely favoured as the method of testing due to the fact that it is easy to be implemented and does not require expensive equipments. ASTM E 1876-09 [2] provided the procedures for determining elastic properties from the measured impulse excitation of vibration. However the standard only applies to specimens with structural shapes of beams, rods and disks. As highlighted in [1], simple structures like beam and rod are easier for direct determination of elastic constants from modal testing to be applied compare to complex structures like plates and shells.

Many researches have been done for finding the most proper procedure for the determination of elastic properties of rectangular plates from modal vibration technique [3-8]. The procedure proposed in [3] seems very feasible and reliable and hence it has been employed in our experiment.

This paper presents the modal analysis of square plates from different materials for determination of elastic constants $E$ and $v$. The results are then compared to the one attained from mechanical testing and theoretical values to evaluate the precision of such procedure.

\section{OVERVIEW OF SPECIMENS}

Two types of materials had been tested. It consisted of stainless steel and glass. Both materials were cut to square plates of $250 \mathrm{~mm} 250 \mathrm{~mm} \times 3 \mathrm{~mm}$ and were marked with nine nodes on the surfaces; as shown in Fig. 1. The stainless steel is an austenitic stainless steel 
having properties similar to the 304 type while the glass is the ordinary sheet glass normally used for windows making.

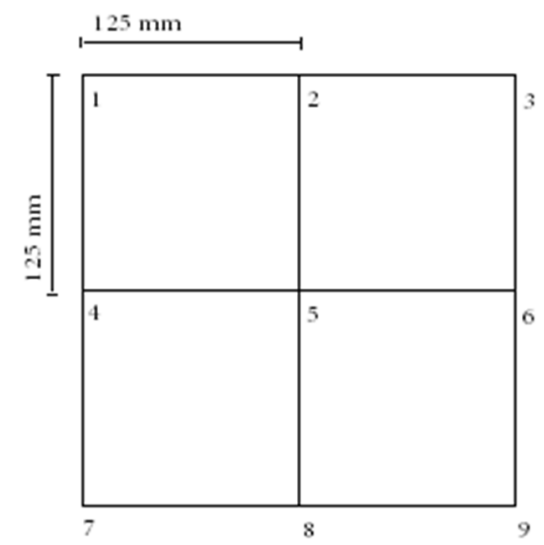

Fig. 1: Schematic representation of a specimen with nodes position.

\section{EXPERIMENTAL MODAL ANALYSIS}

The experimental modal analysis was carried out using the Dynamic Application Group (DAG) Technologies (Malaysia) Sdn. Bhd. [9] instruments using the LMS international [10] software where frequency response function (FRF) measurement technique is employed in extracting the natural frquencies.

For this particular research the modal analysis is done using the method of impact hammer test. This single fixed output testing method which is further described in [11] is one of the most favoured methods for modal testing as it is economical, fast and undemanding in terms of resonance investigation

The specimens were impacted to nine different nodes which were already allocated on the surface of the materials (Fig. 1). For each node, the FRF curve was plotted so that the observation of resonant frequency behavior could be performed thoroughly. The natural frequencies of the plates were then determined from the accumulation of FRF curve behavior of all nodes along with corresponding mode shapes by modal analysis.

Careful observation should be done in determining the desired natural frequencies where all FRF of every node should be studied because a peak of natural frequency could appear in one node but not the other as depicted in Fig. 2-5. The selection of the right frequencies is the essential step in determining the value of frequency ratio hence the values of the elastic constants. 


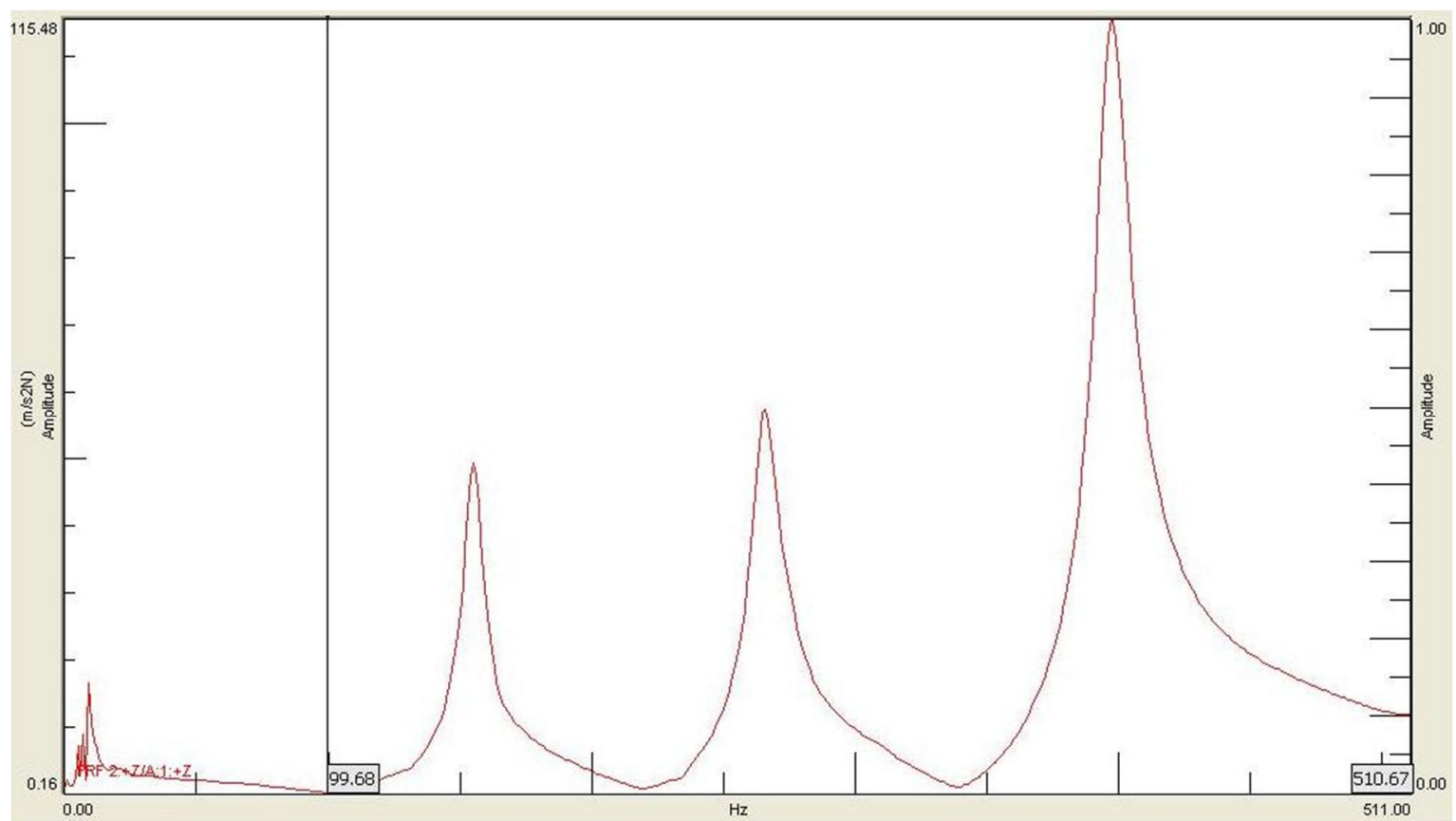

Fig. 2: FRF for the first node of stainless steel.

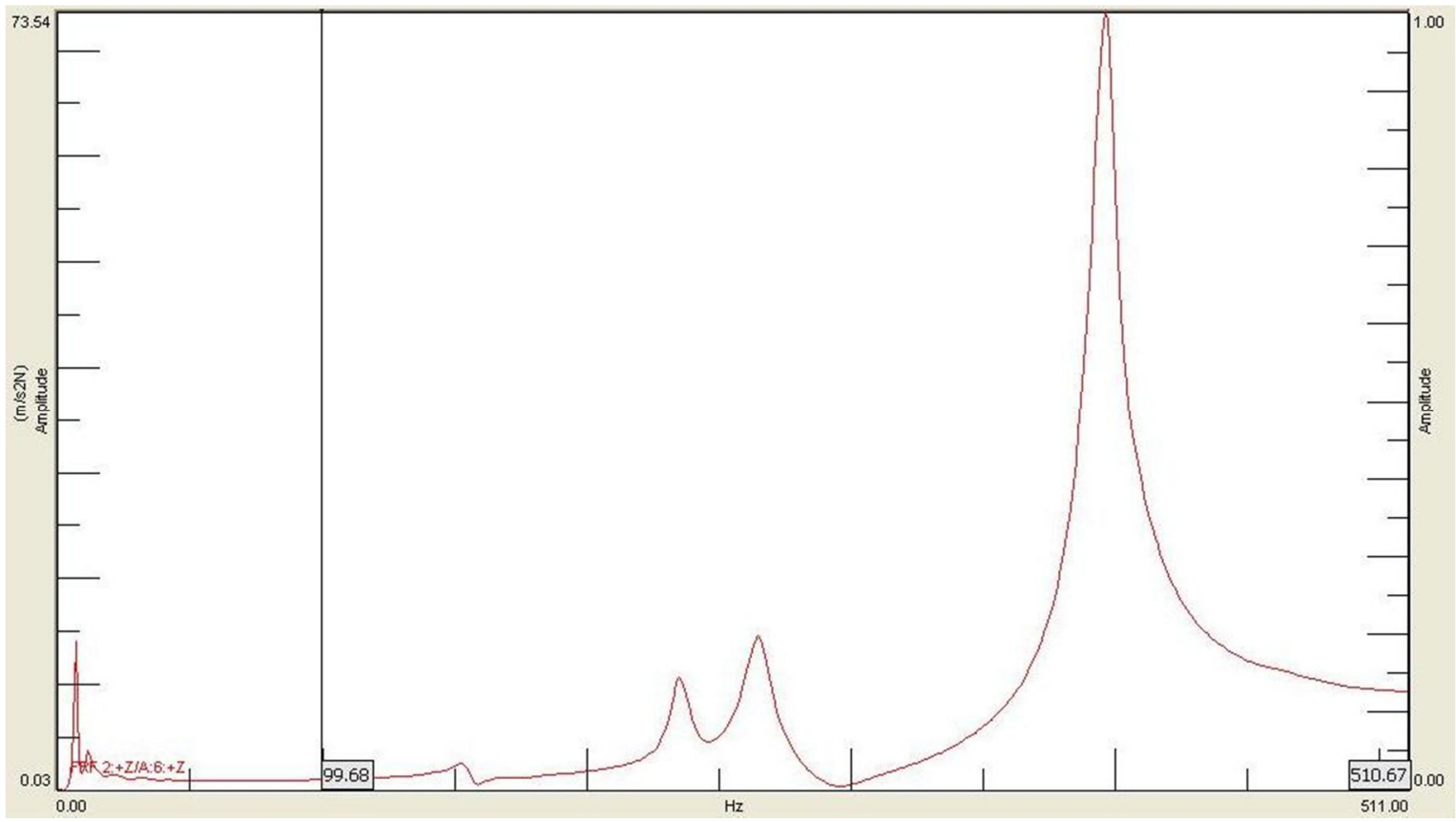

Fig. 3: FRF for the sixth node of stainless steel. 


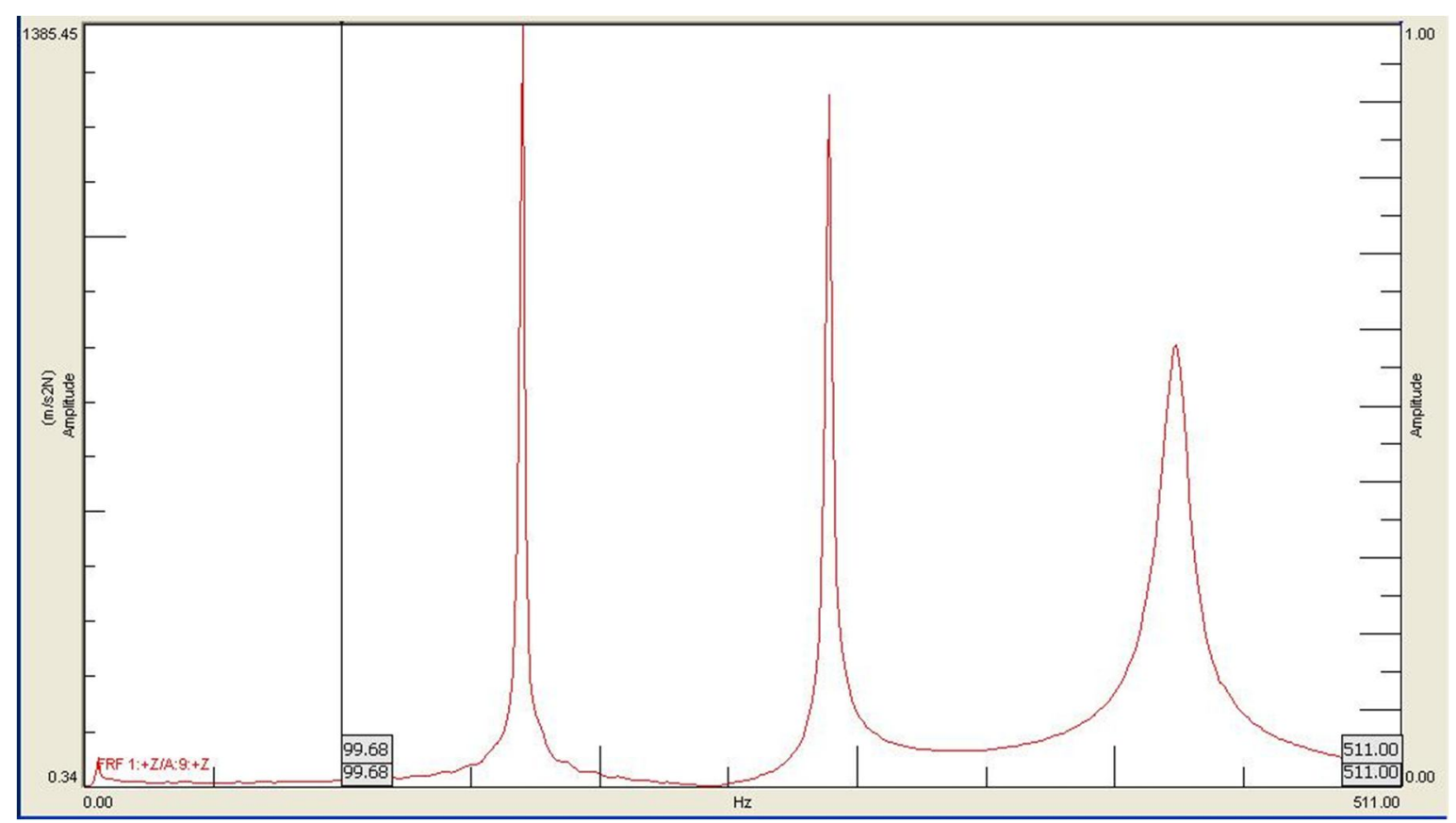

Fig. 4: FRF for the first node of glass.

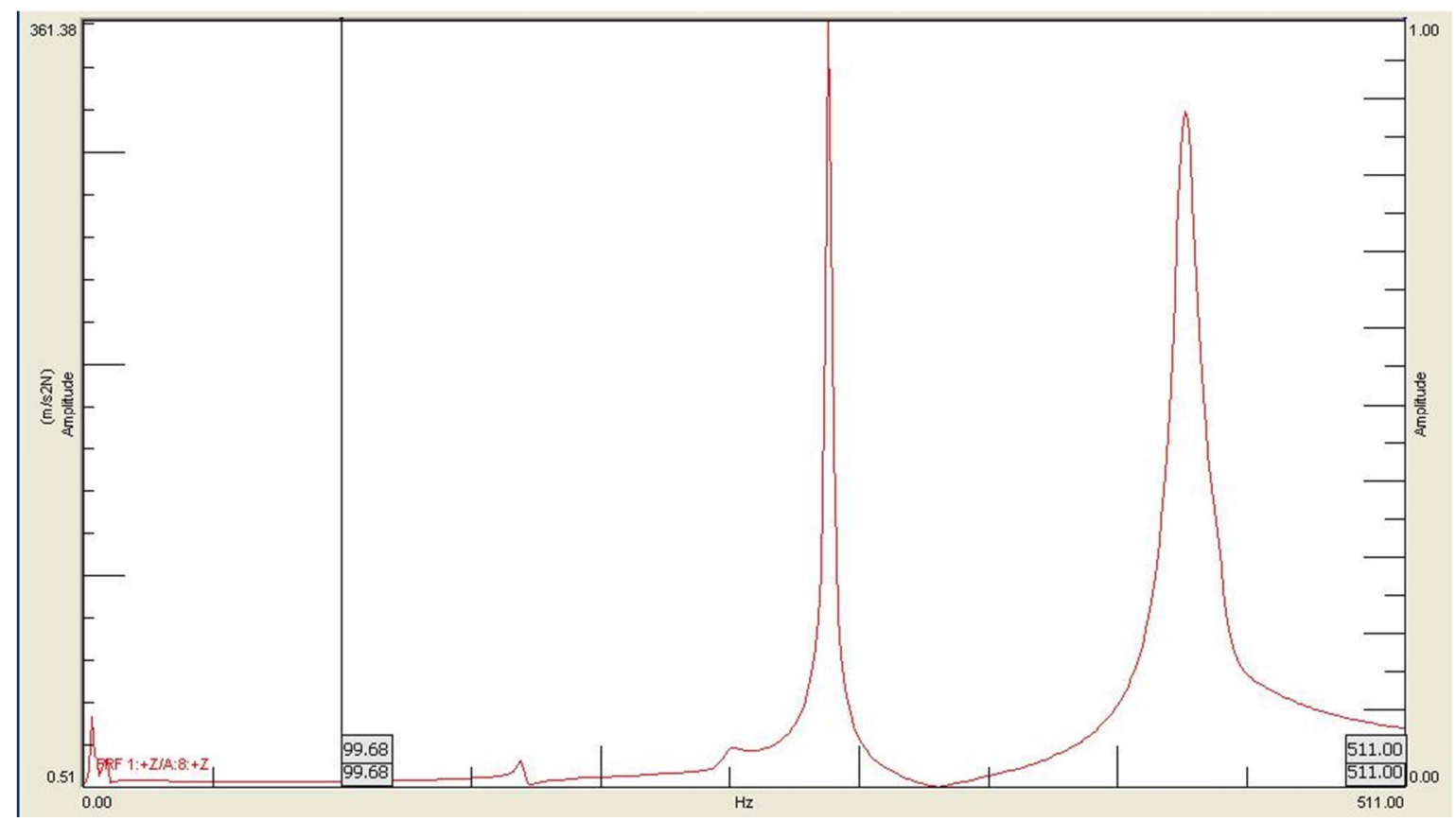

Fig. 5: FRF for the sixth node of glass.

The obtained natural frequencies were then exploited for the procedure outlined in [3] using the formula presented in the same paper:

$$
E=\frac{48}{\pi^{2}}\left(\frac{f}{\lambda}\right)^{2} \frac{m a^{3}\left(1-v^{2}\right)}{b t^{3}}
$$


where $E$ and $v$ are the elastic constants, $f$ is the natural frequency, $m$ is the mass of the material, $a$ and $b$ are the width and length of the sides of the plate, where in this case $a=b, t$ is the thickness, and $\lambda$ is a non-dimensional factor obtained from the table presented in [3] as well.

\section{RESULTS}

Table 1: Dimensions, mass and natural frequencies of materials.

\begin{tabular}{cccccc}
\hline Dimensions, $a \times b \times t\left(m^{3}\right)$ & Mass, $m(\mathrm{~kg})$ & $f_{\mathbf{1}}(\mathrm{Hz})$ & $f_{\mathbf{2}}(\mathrm{Hz})$ & $f_{\mathbf{3}}(\mathrm{Hz})$ & $f_{\mathbf{4}}(\mathrm{Hz})$ \\
\hline \hline Stainless steel & & & & & \\
$0.25 \times 0.25 \times 0.003$ & 1.490 & 156.126 & 233.258 & 264.016 & 400.887 \\
Glass & & & & & \\
$0.25 \times 0.25 \times 0.003$ & 0.468 & 165.439 & 227.142 & 279.802 & 428.809 \\
\hline
\end{tabular}

Table 2: Elastic constants of materials.

\begin{tabular}{lcrrrrr}
\hline Frequency ratio, $f_{j} / f_{i}$ & & $\boldsymbol{v}$ & $\boldsymbol{\lambda} \boldsymbol{i}$ & $\boldsymbol{\lambda} \boldsymbol{j}$ & $\boldsymbol{E i ( G P a )}$ & $\boldsymbol{E j}(\mathrm{GPa})$ \\
\hline \hline Stainless steel & & & & & & \\
$f_{3} / f_{1}$ & 1.691 & 0.224 & 1.430 & 2.419 & 189.81 & 189.81 \\
$f_{3} / f_{2}$ & 1.132 & 0.178 & 2.113 & 2.391 & 198.04 & 198.04 \\
$f_{4} / f_{3}$ & 1.518 & 0.212 & 2.412 & 3.662 & 191.92 & 191.92 \\
Mean values & & $\mathbf{0 . 2 0 5}$ & & & & $\mathbf{1 9 3 . 2 6}$ \\
Glass & & & & & \\
$f_{3} / f_{1}$ & 1.691 & 0.224 & 1.430 & 2.419 & 66.99 & 66.99 \\
$f_{3} / f_{2}$ & 1.232 & 0.293 & 1.993 & 2.456 & 62.59 & 62.58 \\
$f_{4} / f_{3}$ & 1.533 & 0.198 & 2.403 & 3.683 & 68.67 & 68.67 \\
Mean values & & $\mathbf{0 . 2 3 8}$ & & & & $\mathbf{6 6 . 0 8}$ \\
\hline
\end{tabular}

Table 3: Comparison between experimental and theoretical values.

\begin{tabular}{llrr}
\hline Materials & Parameters & Experimental & Theoretical [12] \\
\hline \hline \multirow{2}{*}{ Stainless Steel } & E (GPa) & 193.26 & 193 \\
& $\mathrm{v}$ & 0.205 & $0.3-0.31$ \\
\multirow{2}{*}{ Glass } & $\mathrm{E}(\mathrm{GPa})$ & 66.08 & $50-90$ \\
& $\mathrm{v}$ & 0.238 & $0.18-0.3$ \\
\hline
\end{tabular}




\section{REMARKS}

From the results presented in Table 1-2, it could be seen that the acquired natural frequencies for glass are generally higher than that of stainless steel for every matching mode value. This is due to the fact that the frequency of material is in inverse proportion of mass where in this case, glass, which has lower mass gives higher corresponding frequencies compared to stainless steel.

From the comparison table between the experimental modal analysis testing and theoretical values (Table 3 ), it could be seen that the values for $E$ for both materials are in the range of the theoretical ones but the values for $v$ for stainless steel doesn't really comply to the theoretical value. This may be due to the fact that the ratio of length over thickness, $a / t$ does not equal or exceed 100 as mentioned in [3]. This discrepancy could however be avoided in the future by carefully selecting the dimensions for the plates.

Due to the advantages that this technique has including the ease of use, inexpensive and convenient way of conducting the procedure, it is not a surprise that this technique has been increasingly favoured to be adopted in industries and laboratories. Besides being a nondestructive type of method with great precision, there is a very high probability that the use of such technique would only continue to grow with more research and exploration of how to employ it to future practicability.

\section{CONCLUSION}

This paper presented the use of experimental modal analysis technique in determining the elastic constants for square plates. It was found that the values obtained from this technique are in great precision with the theoretical values despite some inconsistency due to avoidable poor selection of specimens' dimensions.

For future work, this modal vibration technique which provides the knowledge of natural frequencies relationship to properties of materials would be best integrated with the use of artificial intelligence algorithm system such as artificial neural network especially in the area of pattern recognition where some preliminary works could be done in order to create a system of materials identification for easier assessment of characterization of materials.

\section{ACKNOWLEDGEMENT}

The Malaysian Ministry of Higher Education (MOHE) kindly provided funding for the research through the "Fundamental Research Grant Scheme" (FRGS) NO 9003-00222.

\section{REFERENCES}

[1] L. Pagnotta, "Recent progress in identification methods for the elastic characterization of materials," International Journal of Mechanics, 2008, Vol. 2, n. 4, pp. 129-140.

[2] ASTM Standard E1876-09, "Standard test method for dynamic Young's modulus, shear modulus, and Poisson's ratio by impulse excitation of vibration," ASTM International, West Conshohocken, PA, 2003, DOI: 10.1520/E1876-09, www.astm.org. 
[3] M. Alfano, L. Pagnotta, "Determining the elastic properties of isotropic materials by modal vibration testing of rectangular thin plates," Journal of Sound and Vibration, Vol. 293, 2006, pp. 426-439.

[4] A.W. Leissa, Vibration of Plates (NASA SP-160), US Government Printing Office, Washington, DC, 1969.

[5] M.D. Waller, Vibration of free rectangular plates. Proceedings of the Physical Society, London 72 (1949), pp. 277-285.

[6] F. Moussu, M. Nivoit, Determination of Elastic Constants of Orthotropic Plates By A Modal Analysis/Method of Superposition, Journal of Sound and Vibration, Volume 165, Issue 1, 22 July 1993, pp 149-163.

[7] S.F. Hwang, C.S. Chang, "Determination of elastic constants of materials by vibration testing," Composite Structures, Vol. 49, 2000, pp 183-190.

[8] L.R. Deobald, R. F. Gibson, "Determination of elastic constants oforthotropic plates by modal analysis/Rayleigh-Ritz technique," Journal of Sound and Vibration, Vol. 124, 1988, pp. 269283.

[9] Dynamic Application Group (DAG) Technologies (Malaysia) Sdn. Bhd, Malaysia, www.dagtech.com.my.

[10] LMS International NV, Belgium, www.lmsintl.com.

[11] Brian J. Schwarz \& Mark H. Richardson, 'Experimental Modal Analysis', Application note Vibrant Technology, Inc., (1999)

[12] MatWeb - Material Property Data www.matweb.com.

\section{NOMENCLATURE}

$\begin{array}{lll}a & \text { Length } & \mathrm{m} \\ b & \text { Width } & \mathrm{m} \\ t & \text { Thickness } & \mathrm{m} \\ m & \text { Mass } & \mathrm{kg} \\ E & \text { Young's Modulus } & \mathrm{GPa} \\ v & \text { Poisson's Ratio } & - \\ f & \text { Frequency } & \mathrm{Hz} \\ \lambda & \text { Frequency factor } & -\end{array}$

